Original Research Article

\title{
English Language University Teachers' Difficulties in Research Engagement: A Case Study in Vietnam
}

Huong Hoang Le

Faculty of Foreign Languages, Hong Duc University, Thanh Hoa, Vietnam

Article history: Received 30 August 2017; Accepted 15 September 2017; Published 10 October 2017

\begin{abstract}
The study uses a qualitative case study framed within a socio-cultural framework to investigate Vietnamese English language university teachers' difficulties in their research engagement. The study was conducted among 21 English language university teachers in Hong Duc University in Vietnam. Skype semi-structured interview was employed to collect necessary data to explore teacher participants' perceived obstacles to research. The findings of the study show that there was a gap between Vietnamese authorities' expectations of research outputs and the realities of English language university teachers' research capabilities. Such gap has caused serious challenges to those teachers and prevented them from effectively engaging in research. On the one hand, Vietnamese authorities hope to increase universities' research output to keep up with the international academic ranking. On the other hand, the working realities of university teachers hinder their engagement in research. However, no official investigation has been done to reduce such gap and the enforcement of research activity in universities has been taken for granted. In this sense, the significance of this study is an opportunity for English language university teachers to voice their opinions about the enforced nature of research activity in universities in Vietnam.
\end{abstract}

Keywords: English language university teachers; research engagement; Rogoff's interacting planes

HOW TO CITE: Le, H. (2017). English Language University Teachers' Difficulties in Research Engagement: A Case Study in Vietnam. JEES (Journal of English Educators Society), 2(2). 91-100. doi:http:// doi.org. 10.21070/jees.v2i2.979

\section{Introduction}

In Vietnamese tertiary education, research activity forms part of university teachers' workload. Since the publication of The Higher Education Reform Agenda (HERA) 20062020 (Pham, 2010; Sheridan, 2010) was implemented, the role of research activity has come at the forefront of universities goals and operational plans. HERA is a strategic plan for the development of Vietnamese higher education with four main target aims, one of which is the enforcement of research activity in universities. Since introduced, HERA has directly influenced how university teachers react to the reinforced research activity and how they think about their research engagement.

E-mail address: huonglehoang@gmail.com Peer reviewed under reponsibility of Universitas Muhammadiyah Sidoarjo. (C) 2017 Universitas Muhammadiyah Sidoarjo, All right reserved, This is an open access article under the CC BY license (http://creativecommons.org/licenses/by/4.0/) 
Teacher research concept is developed to bridge the gap between research and teaching practice or between theorists and practitioners (Loughran, 2002). In language teaching, attention to teacher research dates back to late 1980s when large-scale studies were conducted to identify the best way to promote language teaching (Allwright \& Bailey, 1991). After that Nunan's work (1989a, 1989b) fostered the preeminent part of teacher research in language teaching. Inheriting and developing precedent literature on the issue, many scholars have recently shown their considerable interest in research-engaged language teachers such as Freeman (1998), O’Brien and Beaumont (2000) and Burns (2010). Regarding English language university teachers in specific, two recent works by Allison and Carey (2007) and Borg (2009) seem to provide an insight into how these language teachers conceive research. The work by Allison and Carey (2007) selected 22 participants from English language teaching staff in a university in Canada. It employed questionnaires and interviews to generate data to explain the participants' aptitude of research and their perceived difficulties. The teachers have to face both external and internal challenges, including a lack of time due, over-loaded teaching job, insufficient motivation and little expertise in research methodology. However, there is a fine line between internal and external constraints to English language university teachers' engagement in research. Aiming at identifying a clear-cut boundary between external and internal barriers to teacher research engagement, Borg (2009) carried on a study of English language university teachers' conceptions of research. The views of 505 teacher participants from 13 countries were studied through questionnaire and follow-up interviews. The study identifies that a lack of time, knowledge and material access are the most referred reasons for those teachers' limited capacity of research. Borg (2009) also indicates that English language university teacher research engagement is largely influenced by practical and professional concerns rather than external factors such as employers or promotion.

Vietnam was not included in these two research projects by Allison and Carey's (2007) and Borg (2009); therefore, their findings cannot fully represent English language university teachers' conceptions of research in Vietnam for the differences of contexts. At this juncture, Hiep's (2006) study conducted among seven English language university teachers in Vietnam promises to craft a closer insight into those teachers' understandings, beliefs, attitudes and actual experiences of research in Vietnamese tertiary context. In his study, problems in conducting research and research dissemination are also discussed. The challenges are English language university teachers' dissatisfaction with current research 
Original Research Article

English Language University Teachers' Difficulties in Research Engagement: A Case Study in Vietnam

Huong Hoang Le

evaluation regulations; a lack of time, materials and opportunities to disseminate research results; and inappropriate university teachers' research training. With the regard to the enforcement of research in university at its early stage, Hiep (2006) was successful in sketching initial problems raised from English language university teachers' research engagement.

However, Hiep's (2006) study was conducted when Higher Education Reform Agenda (HERA) 2006-2020 had not come into operation which meant the enforcement of research in tertiary education had not become an official strategy of the whole Vietnamese education system. While important in contextualizing the Vietnamese tertiary education system prior to 2006, Hiep's (2006) findings do not reflect the current situation of English language university teachers' research engagement in Vietnam when HERA is in the end of its progress. Those gaps remained unaddressed leaving space for my current study which I hope will provide an updated analysis of English language university teachers' perceived difficulties in research in Vietnam.

In this sense, this current study investigates the engagement in research of 21 English language university teachers in Hong Duc University. By involving a small number of participants, the study is expected to provide an insight into English language university teachers' voices of their research engagement's constraints. The study focuses on the sociocultural aspect of English language university teachers' research engagement so as to identify if the current Vietnamese tertiary contexts promotes or hinders these teachers from doing research.

\section{Methods}

2.1 Socio-cultural approach and Rogoff's three analytical planes

Socio-cultural framework is used to investigate factors constituting English language university teachers' perceived difficulties in their research engagement. Moreover, this framework is used to evaluate whether the current Vietnamese research context promotes or hinders English language university teachers' engagement in research. By nature, sociocultural perspective sees human cognition as a dynamic social activity formed through interactions and physically and socially contextualized (Rogoff, 2003; Vygotsky, 1978). In this sense, how English language university teachers perceive their difficulties in research involvement is inter-related with the context where research is performed. 
Rogoff (2003) broadens that theory of knowledge acquisition by seeing the development of knowledge as a mutually constituting process among individuals and cultural processes. Such process is specified in three interacting planes: personal, interpersonal and institutional planes (Rogoff, 1995). Personal plane accounts for individuals' negotiation of meaning for their own understandings, attitudes, knowledge, and so on. Interpersonal plane indicates the mutual relationship among individuals with other people from which arguments, concepts, beliefs, values are established. Institutional or community plane refers to social practices and institutions of given community. All these three planes are inter-related and mutually constituted. In the case of this current study, English language university teachers' difficulties in research involvement is examined in three phases: within teachers' cognition, between teachers with other teachers or people in relations and between teachers with their social and physical context. The institutional plane refers to Vietnam's government, Ministry of Education and Training (MOET), higher education setting, university's physical context and curriculum and so on. The interpersonal plane implies the relationship between English language university teachers and their social partners such as their colleagues, policy makers, researchers and students. Personal plane is indicated by English language university teachers' prior and existing knowledge, their experiences and attitudes and so on. Vice-versa, all those factors in those three planes are reflected on English language university teachers' difficulties in engagement research itself.

\subsection{Participants}

The research participants were selected among university teachers of English in Foreign Language Department in Hong Duc University. I sent invitation packs through email in the format of an attached Word.doc file to 23 English language university teachers (excluding two teachers who were on maternity leave). University teachers who agreed to take part in the research sent back their consent forms through email as an attachment. 21 out of 23 English language university teachers consented to involve in the Skype interview. After that, I contacted 21 interview participants to arrange convenient time and date for interview.

Twenty-one participants were referred to as from P1 to P21 The participants included 5 males and 16 females whose age ranged from 27 to 50 years old. Three participants were currently pursuing $\mathrm{PhD}$ while 19 others had MA degree. Their majors were either English teaching methodologies or applied linguistics with from 2 to 20 years of teaching experience. Their monthly salary varied from 150 USD to 300 USD. 
Original Research Article

English Language University Teachers' Difficulties in Research Engagement: A Case Study in Vietnam Huong Hoang Le

2.3 Data collection and analysis

\subsubsection{Instruments of data collection}

This current study employs Skype semi- structured interview as an instrument of data collection. By the use of open ended-questions, interview offered the interviewees "the opportunity to respond in their own words and to express their own personal perspectives" (Patton, 2002, p. 348) in order to "seek further clarifications, expansion or exploration about a response" (O'Toole \& Beckett, 2010, p. 132). Semi-structured interview, on the one hand, "involves a general set of questions and format which can be modified or varied if the situation demands" (Lichtman, 2010, p. 141). On the other hand, this set of questions "is prepared to ensure that the same basic lines of inquiry are pursued with each person interviewed" (Patton, 2002, p. 343). Skype interview is one type of telephone interview which "helps avoid the safety problems of personal interviews and are much cheaper than these interviews since no travelling cost is involved" (De Vaus, 2002, p. 123).

All interviews were performed in Vietnamese which was the mother tongue of both participants and I to make sure that participants could express their opinions more freely. Each interview approximately lasted for 5 minutes and was recorded. Afterwards, all interviews were transcribed verbatim, translated into English and returned to participants for them to check, modify, and add information before approval.

\subsubsection{Data analysis procedure}

Firstly, the audio records of all 21 interviews were transcribed and translated into English; numbers were then assigned into lines for easy detection of data. Next, those transcripts were read thoroughly several times for overall comprehension. 21 interviewees were coded as from IP1 to IP21 for their confidentiality. Similar or contrasting data was highlighted with the same color and then grouped together to make up themes or categories. Those new themes were then interpreted by contrasting my personal understandings and experiences with the literature reviewed and Rogoff's (1995) analytical planes.

\section{Findings and Discussion}

A great deal of difficulties was specified by all 21 teacher participants. Those difficulties covered both internal and external elements as elaborated by Allison \& Carey 
(2007) and Borg (2009). Accordingly such difficulties were categorized into three Rogoff's (1995) analytical planes.

\subsection{Difficulties from personal plane}

At the personal level, English language university teachers' lack of research knowledge and skills and their obsession with task fulfillment were two biggest drawbacks. First of all, many English language university teachers said their existing knowledge and skills were not sufficient for them to effectively conduct research. This fact echoed with Trung \& Swierczek's discussion (2009). According to the two researchers, lecturers in Vietnam's universities were "weak in terms of research skills and academic knowledge" (Trung \& Swierczek, 2009, p. 566). Additionally, English language university teachers' being de-motivated by pressure from task fulfillment was the second obstacle to the enforcement of research in the university. Rogoff (1995) indicated that motivations helped direct activity so that people could accomplish their goals. From all discussion with teacher participants, although English language university teachers emphasized the role of research to their teaching practice, they seemed to be more obsessed with their task fulfillment. Thus doing research was perceived as a way of avoiding the possibility of punishment such as a termination of monthly extra-money. Such pressure led those teachers to target at research quantity rather than research quality. In this case, doing research to only meet university target did not seem to generate quality research which had a direct impact on teaching and learning experiences of students.

\subsection{Difficulties from interpersonal plane}

Difficulties from the interpersonal plane were caused by administrative staff constraints and rare opportunities for English language university teachers to be exposed to the international academic environment. Administrative staff's constraints referred to their limited competence of foreign language, insufficient knowledge of administrative procedures of editing and publishing research. The story about the university staff's lack of English competence told by the participant IP3 illustrated the first administrative staff constraint. Those who were in charge of auditing and editing research proposals were not good enough at English thus resulted in English language university teachers having to translate their work into Vietnamese. This added to those teachers' already heavy workload. More drawbacks emerged from administrative staff's insufficient understanding when dealing with administrative procedures aimed at supporting research. The participant IP4 once experienced 
Original Research Article

English Language University Teachers' Difficulties in Research Engagement: A Case Study in Vietnam Huong Hoang Le

this when she carried on an organizational-level research project and applied for subsidized funding from the university.

IP4: It (paperwork) is really complicated. It takes much time to complete, and the staff is not helpful at all.

This participant (IP4) concluded that the administrative staff's lack of understanding of research procedures was an obstacle against university teachers' engagement in research and then hindered research capability in the university

The second difficulty was caused by little exposure to the international academic environment. English language university teachers hardly exposed themselves to the wide world by attending international conferences or sending research articles to foreign journals. As a result, their chance to work with foreign scholars on research projects was almost zero. Their expectations of exchanging knowledge with foreign researchers could not be achieved either.

\subsection{Difficulties from institutional plane}

Difficulties from the institutional plane were originated from limited access to material resources, overloaded work and insufficient affordability of research. Some of these difficulties resonated with Hiep's (2006) findings. Such shared difficulties were a lack of time, materials and opportunities to disseminate research results.

Concerning limited access to material resources, teacher participants commonly agreed that the university's library could not satisfy their research's needs

IP1: Our university's library is not a potential source of materials. It is worthless finding necessary materials there.

IP2: Material source is a big problem. The university's library can not meet research demands.

When the university's library was not a promising source of materials, those teachers found their essential materials by searching the Internet (IP1) or asking for help from their friends (IP4) or their colleagues (IP2). Such English language university teachers' effort to find research materials took them much time and lengthened research process.

One another major constraint to English language university teachers' engagement in research was the enormous workload that they were expected to accomplish. Officially, the 
teachers were annually assigned 280 periods of teaching activity, 180 periods of research activity and an approximately similar amount of other sub-activities. In reality the number of teaching periods exceeded the standard workload.

IP2: Besides doing research, I have to conduct lectures and do other tasks. I can not devote all of my time to research. Furthermore, teaching workload is so... so... big.

IP3: I am in charge of a big number of teaching periods which exceed the workload standard.

In Vietnam, every university student needs to learn English as part of the requirement of their degree. However, there is a limited number of English teaching staff. This situation placed English university teachers under enormous pressure and excessive workload, resulting in a lack of enthusiasm to engage in research activity. Over-loaded work led to time constraints when teachers did not have much time to devote to research activity after long teaching hours. Such causal relationship between over-loaded work and insufficient time was consistent with the findings from two studies by Allison and Carey (2007) and Borg (2009). In this regard, a lack of time and over-loaded work were more likely common challenges to English language university teachers' research engagement in different contexts.

Another factor impacting on research output was the affordability of research. There was official funding for national, provincial and organizational-level research projects (Personal communication with the Head of the Department of Scientific Research). However, expenses for publishing research articles and conducting lower-level research projects had to be covered by English language university teachers themselves. Those published articles and approved lower-level projects went towards the assigned 180 periods of research activity but the cost of these research initiatives were not reimbursed to those teachers. The difficulty was that not all teacher participants had access or opportunities to engage in organizational-level or higher-level research projects. They mainly involved themselves in research activity by sending articles to domestic journals, doing lower-level projects and attending workshops or conferences; therefore, they had to bear all the cost when doing research.

IP3: I only conduct mini projects (divisional or departmental-level ones) which are of department level and it is the fact that I have to pay all expense.

IP4: By financial problem, I mean that the university's subsidized funding is not much. Thus if teachers want to devote to research, they have to care about funding themselves (Laughing). 
Original Research Article

English Language University Teachers' Difficulties in Research Engagement: A Case Study in Vietnam

Huong Hoang Le

This burden of finance seemed to be a cause of stress for English language university teachers. On the one hand, the university tasked their teachers to a certain amount of research activity. Some kinds of punishment (a termination of monthly extra- money) were applied if teachers could not complete their compulsory workload. On the other hand, it appeared that the university's support was limited leading to the English language university teachers to self-fund their research to meet the target publications.

\section{Conclusions}

In conclusion, the study revealed English language university teachers' perceptions of constraints when engaging in research. Framed by socio-cultural perspective, such perceptions informed and were informed by Vietnamese tertiary context. Interpretations from English language university teachers' voices demonstrated achievements and drawbacks of the enforcement of teacher research engagement in universities in Vietnam. Research in Vietnamese universities seems to be on the right direction when spreading the culture of research among university teachers. However, some challenges caused by policies and regulations were fairly serious which needed amending to improve university teachers' research capabilities in general and English language university teachers' in particular.

\section{Acknowledgments}

The author would like to thank Dr. Corine Rivalland for her excellent comments. She would also like to extend her thanks to anonymous reviewers for their critical reviews that greatly improved the manuscript.

\section{References}

Allison, D. \& Carey, J. (2007). What do University Language Teachers Say about Language Teaching Research?. TESL Canada Journal, 24(2), 61-81.

Allwright, D. \& Bailey, M. K. (1991). Focus on the Language Classroom: An Introduction to Classroom Research for Teachers. Cambridge: Cambridge University Press.

Borg, S. (2009). English Language Teachers' Conceptions of Research. Applied linguistics, 30(3), 358-388.

De Vaus, D. A. (2002). Surveys in Social Research (5th ed.). Australia: Allen \& Unwin.

Freeman, D. (1998). Doing Teacher Research. Boston: Heinle and Heinle.

Hiep, H. P. (2006). Researching the Research Culture in English Language Education in Vietnam. TESL-EJ, 10(2), 1-20.

Lichtman, M. (2010). Qualitative Research in Education: A User's Guide (2nd ed.). Thousand Oaks, Calif: SAGE Publications. 
Loughran, J. (2002). Teachers as researcher. In J. Mitchell, J. Loughran, \& I. J. Mitchell (Eds.), Learning From Teacher Research (pp. 3-18). New York: Teacher college press.

Nunan, D. (1989a). The Teacher as Researcher. In C. Brumfit \& R. Mitchell (Eds.), Research in the Language Classroom (pp.16-32). London: Modern English in association with the British Council

Nunan, D. (1989b). Understanding Language Classrooms. New York: Prentice Hall.

O'Brien, T. \& Beaumont, M. (2000). Collaborative Research in Second Language Education. Stoke-on-Trent: Trentham Books.

O’Toole, J. \& Beckett, D. (2010). Educational Research: Creative Thinking and Doing. Melbourne: Oxford.

Patton, Q. M. (2002). Qualitative Research and Evaluation Methods (3rd ed.). Thousand Oaks, Calif: SAGE Publications.

Pham, T. N. (2010). The Higher Education Reform Agenda: A Vision for 2020. In G., Harman, M., Hayden \& T. N. Pham (Eds.). Reforming Higher Education in Vietnam: Challenges and Priorities (pp.51-64). The Netherlands: Springer.

Rogoff, B. (1995). Observing Sociocultural Activity on Three Planes: Participatory Appropriation, Guided Participation, and Apprenticeship. In J. V. Wertsch, P. D. Rio \& A. Alvarez (Eds.), Sociocultural Studies of Mind (pp. 139-163). New York: Cambridge University Press.

Rogoff, B. (2003). The Cultural Nature of Human Development. Oxford: Oxford University Press.

Sheridan, G. (2010). Vietnam: Preparing Higher Education Sector Development Project (HESDP). ADB

Trung, Q. T. \& Swierczek, W. F. (2009). Skill Development in Higher Education in Vietnam. Asia Pacific Business Review, 15(4), 565-586.

Vygotsky, L. S. (1978). Mind in Society: The Development of Higher Psychological Processes. Cambridge, MA: Harvard University Press. 